\title{
Research of Music Talent Cultivation Based on Practice Education
}

\author{
Yumeng He \\ School of Music \\ Liaoning Normal University \\ Dalian, 116029 China \\ dl_hym@126.com
}

\begin{abstract}
Based on the concept of music practice education, this paper designs a music talent cultivation mode from the perspective of the "credibility" of educational objective. This paper analyzes the realization strategy of music teaching and training from mutual fusion among teacher, students and training objective by modern teaching theory, learning theory and relevant educational psychology theory. By analyzing the fusion between student's individual attribute of music cognition process and the music performance, it proposes an objectoriented music teaching mode based on practice education, thus to achieve credible targets of music talent cultivation.
\end{abstract}

Keywords-music higher education, practice academic, music social cognition, quality of music performance, reform of teaching and learning

\section{INTRODUCTION}

Music higher education or continuing education plays a necessary and an increasingly important role of music team construction and development in China [1]. The role of music colleges in music higher education development is vital, but it is also complex and dynamic. Music colleges exhibit numerous different capabilities and scope, and can affect processes of development both directly and indirectly through talent cultivation, knowledge innovation and social service. Furthermore, music colleges operate within different music skills demand in which they can play numerous roles and face various challenges. And while there are many challenges in providing adequate education in pursuit of certain goals, there are also promising improvements in music higher education that increases the impact, quality and effectiveness of Music College's role in development and music work change.

Besides, problems existing in the operation modes advance specific research contents for the music higher education system. Under different operation modes, music education system as well as management incorporated into one body, the professional capability will assume different knowledge demand. In many literatures [2-4], the researchers basically categorize professional capability of music into management science, social science, and music knowledge demand and information technology. In the field of research on music skills, Music College have long played a key role, while in the field of social science and information technology research has been undertaken more recently. More and more attention is now being paid to this field. In recent years the research of music colleges in the educational goals, specifications of talent cultivation has been given greater prominence in many literatures [5-7]. The purpose of music higher education is cultivation music science and skills of college students, including the knowledge of music theory, and the skills of music practice, which are conducive to individual profession capacity. This paper, based on the research of Refs [1-9], will conduct research on issues relating to music profession from the perspective of music team development strategy.

The paper is structured as follows: Sections 2 contain the author's main ideas on how to research on social cognition, music practice and music knowledge and skills role to quality of talent cultivation. Basic ways and requirement of music cooperation education, which is discussed in section 3. Finally, section 4 contains the main conclusions and future work.

\section{EduCATION MOdE OF MUSiC COLLEGE}

\section{A. Structural Drawing of Music Higher Education}

The historical experience and theoretical research on music education have shown that the development of Music College is mainly reflected in the effective synergy of the three major factors - operation modes, operation object and knowledge systems in addition to music education systems. Advancing the social means and operation modes parallel with the advances in knowledge systems will become the development trend over the next two decades. In particular, in planning and design of music higher education development strategy of a country or various regions, the issues of operation modes and objects are taken out as a special topic for research, thus demonstrating their significance to the research. [1]

However, these researches all ignored a crucial problem, i.e., the relationship between social policing needs and operation model of Music College. Music higher education is generally understood to talent cultivation, knowledge innovation and social service. If we critically analyze the different concepts of music higher education, we can list the various roles music higher education plays in the society. Music College provides opportunities for lifelong learning of music, allowing people to upgrade their knowledge and skills from time to time based on the needs of the music work. As the music education and training is a systematic engineering, therefore, a music education and training operation system in line with social and economic development must be established. Under different knowledge innovation, talent cultivation and social service levels, corresponding to a music knowledge system, social 
perception process and music cognition model will be formed. Therefore, basic structure of music higher education operation system can be established with regard to the music science, music skills, and music knowledge. [2]

Music higher education is also seen as cultivating and inculcating professional capability and moral values in music jobs. As such, the Music Colleges play an integral role in the music team construction and development. Knowledge-based approaches, including fitness education theory and critical pedagogies borrow heavily from the profession capacity of music. How do the benefits of fitness music higher education permeate profession capacity and impact larger music model change? What aspects of fitness music education enable by the music higher education as agents of music innovation and how can this education best serve as a catalyst for music jobs development?

In the "standard" conception of music education, music colleges constitute a form of specialized profession education and training. What used to be referred to as "music man-power planning," music higher education provides the music knowledge base, music skills, and training to perform specific tasks and jobs of social management. In social music terms, "music-power capital" adds higher levels of music education and competency to social function for music. Music capacity development is another similar term sometimes used to describe this social role of music higher education.

\section{B. Music Cognition Process}

The theoretical construct predominantly used when studying music cognition and education practice is a social perception systems theory (SPST). SPST is self-reflexive and is a cybernetic input-throughput-output-feedback model. The present research used music cognition model, based in SPST, to understand the social practices of music college students. We also examined the data through the lens of SPST. [1]

The four stages in the music cognition model, as developed by Literature [1], explain how Music College's students make social decisions and develop social behaviors. The stages are inputs, throughputs, outputs, and feedback loop. For this study, we only examined the inputs and throughputs sections of the model and added the environmental influences of family and school. The outputs and feedback sections of the model were beyond the scope of this study. To measure outputs and feedback requires longitudinal data, which the researcher did not gather for this study. SPST helps explain the environmental influences Music College students have had over the years shaping them into who they are today.

The attitudes and behaviors college students have about music cognition come from their home environment. As students learn over the years through social interaction, they begin to understand and form their values, knowledge, and attitudes about policing management. Family, friends, community, nation, school, church and media all shape college students' knowledge and attitudes over time [2]. This study combines SPST and family cognition influences theory (FCIT) in a way that considers environmental influences that shape where a person currently is in regards to their knowledge, attitudes, and personal characteristics.
The focus of this study is the music knowledge, attitudes, and behaviors of college students along with the two key environmental influences of family and college that help shape students current status. The environmental influences of family and college focused on for this study because of the great influence they have on music college students' social knowledge, attitudes, and behaviors. Family tend to have a greater influence on students at a younger age while peer influence increases as the student becomes older and especially after becoming a music college student. The addition of these environmental influences to our understanding of college students' social knowledge, attitudes, and behavior is a major contribution of this study.

\section{Practice Education for Music Colleges}

Academic research at music colleges plays an indispensable role in music higher education development, albeit a very complex and perhaps an indirect one. Not only does it create and increase knowledge and ways of understanding, but research also informs policy decisions. As such, academic research is important for the independent development of a music college itself, as well as for government policies. Whether conducted for specific purposes (action research) or as an academic pursuit by policy makers or academics, research has an impact on all areas, especially in the context of human and social development. That is to say, "Academic research of policing management is assumed to be a vital part of the role of music colleges.

However, there is a growing need to question the paradigms of knowledge and innovation that inform the research carried out by music colleges and its application in wider social practice; and the way that society and music team development needs shape the research agenda itself.

Despite its widespread use in literature, the traditional way of conceptualizing music capacity solely as either music skills or music knowledge is deemed inadequate to encompass the visions of education in the 21st century. Music cognition is a process of turning music knowledge, attitudes and behavior into meaning, understanding, and new ideas. This process would require students to understand the rationale behind using knowledge as well as actually knowing the exact procedures of conducting the information search. Students need to 'know-how', but more importantly, they must first 'know-why'. Hence, being music cognition would contribute towards personal empowerment through the learning to learn. [3]

The emerging digital culture coupled with the trends in economic globalization and the quest for a knowledge-based society have been creating tremendous momentum to drive the development and infusion of social cognition in education and all spheres of political, economic and social life of the twentyfirst century. In this regard, we argue that music cognition should be framed in a way to empower students to develop in them the capacity for lifelong learning, and to assume greater autonomy and social responsibilities over their learning. The notion of music cognition should be broadened to embrace a wider spectrum of learning outcomes manifested in different dimensions of learning in the information age.[4] 


\section{RESEARCH OF TEACHING AND LEARNING OF MUSIC COLLEGE}

\section{A. Education and Training}

A key component of quality in teaching and learning of Music College involves quality of music performance by the learner. Music College for training is made in attempts to address problems in the quality of music performance. These efforts have met with minimal success, and major gaps in the standards to which students have been trained and their resulting performance remain. Music College note that the expected performance in a music work setting is generally dictated by a set of valid and appropriate expectations and is attained through proper education and training. When music performance consistently adheres to the appropriate expectations, then quality of music performance is achieved. If there is a discrepancy in music performance and appropriate expectations, then it must be investigated, causes identified, and appropriate corrective action taken. [5]

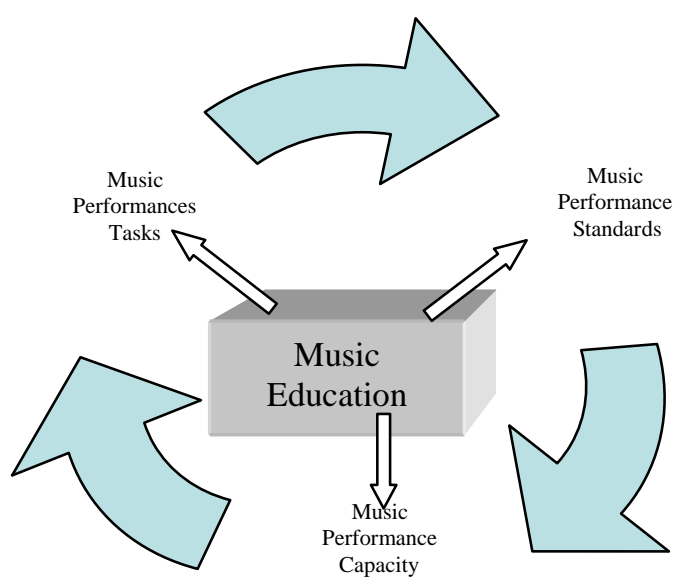

Fig. 1. Education and training based on Quality of music Performance

To achieve quality of music performance, we posit that three components must be present:

- A clearly defined set of tasks to perform.

- An individual that has the capacity/ability to perform the required task.

- A clear set of standards that define successful music performance.

Music training and education provide the skills, knowledge, abilities, and attitudes to perform the tasks to standard. In Fig. 1 all three variables are conceptually displayed inside a circle of quality of music performance. [6]

\section{B. Teaching Reform Based on Quality of Music Performance}

The components are in constant motion: the music work to perform (either practice academic or practice tasks), the rules of music behavior (what it takes to be successful), and the music performer. The key to this process is the underlying self-regulation factor. The quality of music performance can be seen as a complex process of balances where several factors have to work together to ensure success with one of the main factors as self-regulation. When the model of quality of music performance was applied to the teaching and learning of Music College found students were fully cognizant of the behaviors necessary for academic success, but they often chose not to engage in these music behaviors. They fully recognized the discrepancy in their music behaviors (what they should do versus what they are doing), but they also did not choose to engage in self-correction.

Instead they expressed the expectancy that the standards of music performance would, and should, be negotiated in their favor. This very act of renegotiating the standards of policing performance suggests that music department will not necessarily find future music that possesses the skills expected based on their college academic experience. Customers in music department may soon force Music College to take a long and hard look at the "product" they are producing. Music College is beginning to learn those music departments are less likely to accept these modifications in standards, which lead to a graduate who does not meet standards. [7]

According to music work the learning goals of a student's major involve demonstrating "a substantial body of knowledge about a social management field, learning music techniques to search for information and analyze it in illuminating ways, and ultimately using these methods to address problems of substantial complexity." Certainly these are also relevant to performing a music work well when a student has been hired for his/her expertise in a specific area. More interesting, however, is the overlap between music work and higher education in citing general knowledge and skills that should be present regardless of a student's major. Some of the skills and knowledge considered important by both music work and higher education include:[8]

- Critical thinking

- Oral communication

- Written communication

- Reading comprehension, cultural diversity

- Ethics/social responsibility

- Information technology

- Adaptability

Music department should be able to expect students with a college degree to show reasonable proficiency in these areas. On the other hand, that entering music college should expect opportunities to develop competencies and be held to standards of music performance in these areas. Finally, faculty of Music College should take steps to ensure these areas are addressed in their courses and are part of the quality assessments for their college.

If Music Colleges focus on satisfying students as their primary customers, they may negatively affect another customer group-employers-because the two customer groups have significantly different ways of defining and measuring expectations. There are no easy solutions to addressing the negotiation of standards that undermine quality of music 
performance. Music College, faculty, students, and music department can serve as contributing architects in ensuring education establishes quality standards. They are all consumers, and they all have a vested interest in maintaining standards. [9]

\section{CONCLUSIONS}

The music talent cultivation mode is an important part of reform and innovation in music higher education. However, the existence of own meaning which higher education of different areas in the specifications and quality of talents cultivation. The significance of research and design of the music practice education is seeking to make education quality for educator and the acceptance, the degree of acceptance is called "credibility". In addition, there are many uncertainties in the aim of teaching, education and training, how to solve the uncertainty of music education process, how to improve the credibility of cultivating talents, how to construct a teaching mode is satisfactory for teachers, students, society to accept, it is an important issue of the music education practice The main contribution of this paper: proposed a concept of credible practice education, to construct the credible learning mode with music performances tasks, music performance standards, music performance capacity in practice education, the teaching theory of constructivism and "differences" teaching mode from a certain angle supplements.

\section{ACKNOWLEDGMENT}

The authors are grateful for the support given by 2014 teaching reform project of undergraduate course of higher education of Liaoning Province (No: UPRP20140525). We also thank reviewers for insightful and helpful suggestions.

\section{REFERENCES}

[1] Yumeng He, Research and design of Music Cognition Education Mode for Music Schools, 2014 IEEE Workshop on Advanced Research and Technology in Industry Applications, 2014, pp.510-513.

[2] Yumeng He, Music Talent Cultivation Based on Credible Education Theory, 2015ACSS International Conference on the Social Sciences and Teaching Research, 2015, pp.170-175.

[3] Anderson, E. S., Winnett, R. A., \& Wojcik, J. R, Self-regulation, selfefficacy, outcome expectations, and social support: Social cognitive theory and nutrition behavior. Annals of Behavioral Medicine, 2007, vol.32, pp. 304-312.

[4] Bandura, A, Social cognitive theory: An age ntic perspective. Annual Review of Psychology, 2001, vol.52, pp.1-26.

[5] Taymoori, P, Rhodes RE, Berry, Application of a social cognitive model in explaining physical activity in Lranian female adolescents. Health Education Res, 2010, vol., pp.257-267.

[6] Mehta P, Sharma M, Bemard A, Social cognition theory as a predictor of dietary behavior and leisure time physical activity behavior in middle-aged Asian Indian women residing in United States. Int $Q$ Community Health Education, 2010, vol.30, pp.257-269.

[7] Sallis JF, Grossman RM, Pinski RB, Patterson TL, Nader PR, The development of scales to measure social support for diet and exercise behaviors. Prev Med, 1987,vol.16, pp.825-836.

[8] Yumeng He, Research of Music Literacy Model for Music Schools Students, 2015 SSR International Conference on Social Sciences and Information, 2015, pp.99-104.

[9] Ping He, Education Matter-element Analysis and Extension Model for the Control of Higher Education Quality, 2014IEEE Workshop on Advanced Research and Technology Industry Application, Ottawa, Canada, 2014, pp.514-517. 